\title{
Peter Kirkegaard
}

\section{Lille receptionshistorie}

\section{Indledning til Harald Steinhagen: »Om Walter Benjamins allegori-begreb«.}

Modtagelsen af Walter Benjamins værker og værk er gået ad krogede veje, herhjemme $i$ endnu flere springvise etaper og etager end $i$ det tvedelte hjemland, hvor den logisk nok er adskilt $i$ to hinanden bekrigende.

Omkring 1970 dukkede han op, i Vindrosen, Kritik og mange andre steder, dels i essay-oversættelser, men især og mere blivende i referat, i introduktioner, universitetsopgaver og i suggestive citater i kulturjournalistikken.

Den første fase var karakteristisk ved at 'bruge' Benjamin direkte, aktuelt, aktivistisk. Man tog specielt hans mediehistoriske essays frem, uddrog deraf de mest æggende og risikable af hans (kultur)politiske fordringer og lod dem gælde for mere end de var; der var rus i det, det sidste pift af anarkisme i universitetsverdenen, inden den store klogskab satte ind.

Midthalvfjerdserne så flere kritiske essays om den mærkelige Benjamin. Efter Peter Madsens inspireret igangsættende arbejde kom efterrusen, man skilte med hård hånd klinten fra hveden. $\mathrm{Og}$ der blev ikke meget tilbage af den hele Benjamin, hvis rødder jo var jødisk-mystiske, idealistisk mistænkelige. Noget vigtigt var rigtignok på færde hos Benjamin, men videnskab var det ikke, desværre. Videre måtte man jo, og undervejs kunne man da godt tillade sig at krydre strabadserne med en velvalgt og godt lagret aforisme af den ureglementerede tænker, skrive kunne han jo!

Let karikeret som denne lille historie er, har den dog typiske faser og overgange. Logik er der også i den, på flere oplysende måder. For det første er jo allerede tysken som fremmedsprog et problem, der skiller mange afgørende ud. Sammenhængende dermed er der dernæst det eneste oversatte udvalg af Benjaminessays' dårligdomme, der for ét vigtigt essays vedkommende var vejen om ad svensk før det nåede danske øjne. Dem måtte man sandelig gnide, for den svære Benjamin krydredes ekstra af omvejen, mildt sagt ('Kulturindustri'. Rhodos 1973). 
Logisk er det naturligvis også, fornuftigt at tage forbehold over for Benjamin, der desperat optimistisk pressede sin tanke i mellemkrigstidens modsætninger, og bl.a. var tvunget til at benytte korte, tæet koncentrerede former dertil. Storværket, livsværket, 'Passage'arbejdet, 'Paris, det 19. århundredes hovedstad', forblev en torso.

Ydermere voksede filologien støt. Øst- og Vesttyskland havde separate kilder, og først i 70-erne begyndte Suhrkamp den lange række af 'Gesammelte Schriften', som endda næppe bliver den endelige. Nid og nag, hemmelighedskræmmeri og politiske modsætninger, skoler og retninger - alt dette har gjort det forståeligt, at mange har slået sig til tåls med det éngang opfattede. Og vé den student, der $n u$ skal begynde at bestige bogtårnet! For nok er bygningen ved at være fint synlig, men den gejst, der førte mange gennem adskillige lag af højst værdiladet overlevering, hvor skal den komme fra, midt i filologiens autoritative støv? For lønner den store møje sig, hvis manden alligevel var mystiker og kun delvis $\mathrm{i}$ sine sidste år kom $\mathrm{i}$ nærheden af sandheden?

Det er naturligt nok Benjamins tidlige fase, 20-ernes habilitationssøgende, jødisk-metafysiske kunstteoretiker, det har været vanskeligst at komme nær og goutere. I stort omfang har man da simpelthen fortrængt denne fase, draget sine pointer i 30-erne, omkring mediepolitikken, storby-temaet og delvis den historiske hermeneutik eller historiefilosofi - og ellers fortsat i egne spor. Karakteristisk i denne forstand er også den efter min mening grundigste danske indføring, Mikael Westergaard-Nielsens 'Walter Benjamin' (i 'Litteraturkritik'. Borgen 1979). Man får virkelig god besked her, men der er ét begreb, som praktisk talt glimrer ved sit absolutte fravær, skønt det også for den sene Benjamin, der fortolkede Baudelaire og historien, var helt centralt, nemlig allegorien. Sandt at sige er det nok også det vanskeligst opgravelige af Benjamins kernebegreber, fordi det kun sjældent er direkte tematiseret og dog samtidig bestandig er til stede. Når man får øje for det. Men holdningen har især været - og jeg er vidende om fortræffelige undtagelser - den, at allegori-begrebet var og blev idealistisk inficeret og iøvrigt desværre, for ubelyst hvad angik den sene Benjamin.

Men det virkelig problematiske er jo spørgsmålet, om det overhovedet er muligt at skille et så tætknyttet filosofisk livsværk som Benjamins ad uden at miste det vigtigste. En slags 'tankeforbud' synes at være slået ind, det dér kan vi ikke befatte os med, i hvert fald! (Om så den århundredelange bagtalelse af allegorien spiller med, det ved jeg ikke!). 
Sagt på en anden måde: tiden er máske inde til at undersøge sammenhængskraften og ikke blot konstatere bruddene i Benjamins udvikling, for hvis f.eks. Baudelaire-studierne har noget for sig, så kunne det nok være, at det habilitetskasserede Frühwerk 'Ursprung des deutschen Trauerspiels' (1928) også havde det, al angivelig idealisme til trods. En tankeform af mere holdbar art end den de politiske konjunkturer tvinger er måske på spil?

Tidspunktet for at stille sådanne spørgsmål synes rimeligt. For nu endelig er de hemmeligste af alle Benjamins hemmelige papirer blevet offentligt tilgængelige, hele Pariserpassage-torsoen, alle konvolutterne, som de særligt indviede længe har kunnet citere godbidder fra (Gesammelte Schriften, Band V. 1-2: 'Das Passagen-Werk'. Suhrkamp 1982 - en filologisk lækkerbidsken).

Samtidig forekommer ordet allegori nu at være blevet lidt af et modeord, som der i kulturjournalistikken klattes med næsten som med varefetichen for 10 år siden. Modsætningen til forskningens tavshed er slående, og ufrugtbar. Med et ben begge steder har jeg selv klattet med, men mener iøvrigt, at allegori-begrebet tvinger sig på, eftersom snart sagt hver anden Hollywood-film handler om katastrofen og undergangen, og eftersom forfaldet tager til på mange fronter og i det hele taget tvinger til udsagn, der vil generalisere den lokale misère i det enkelte kunstværk, det være sig bøger, film, plader osv.

Jeg er ikke ude på at anbefale allegorien - det kan man ikke, for da er man allerede ideolog i dărlig forstand. Men allegorien synes at opstå - på uformodet måde - når billedet og tanken med nødvendighed søger hinanden. Og så bliver det kulturpolitisk vigtigt at kunne skelne mellem den platte og den kritiske allegori, ligesom også den videre forskning i de benjaminske spor angående medier, storby osv. kunne fordybes derved.

Er man da først blevet nysgerrig, kunne man godt forvente sig en del af det germanist-symposium, som i september 1978 afholdtes i Wolfenbüttel i BRD under den løfterige fællestitel: 'Formen und Funktionen der Allegorie', og som året efter udsendte samtlige skriftlige oplæg og mundtlige diskussioner under samme titel - en moppedreng på 800 sider (udgivet af Walter Haug, J.B. Metzlers Verlagsbuchhandlung, Stuttgart 1979).

Men for germanisterne, der er filologer i en forstand vi næppe kender mere herhjemme, er Benjamin åbenbart det virkeligt store filosofiske dyr, hvem fornuften knap kan befatte sig med. I hvert fald er der kun ét oplæg, der direkte omhandler Benjamins allegori-begreb, det her oversatte af Harald Steinhagen fra Bonn 
- som da netop også starter med at reflektere over denne generelle 'fortielse'.

Steinhagens indlæg kan til gengæld nok siges at udgøre en rimelig introduktion til det rigeligt gådefulde emne. Det er svært at læse, forudsætter nok, at læseren har en slags helhedsbillede af Benjamin i forvejen.

Hvad hans allegori-begreb angår, så har dette blad i øvrigt allerede flere gange forsøgt - mer eller mindre helhjertet - at få skovlen under allegorien (Anker Gemzøe i nr. 22, Lars Mjöset i nr. 28, og - delvis - Martin Zerlang i nr. 32). Groft sagt er allegorien for dem alle tre en nogenlunde fast fixerbar størrelse, der, som Steinhagen skildrer Barok-allegorikerne, diktatorisk individuelt forsøger at fortolke feudalismens synkende skude på ret køl igen jvf. Steinhagen s. 98: »- man spørge sig: i hvis interesse«.

Hvad Steinhagen har fremfor dem er netop sansen for bevægeligheden i Benjamins allegori-tænkning, dens dobbelthed af proces og stivnet billede, brud og sammenhængskraft. Hverken Benjamin eller Steinhagen propaganderer primært allegorien, men har blik for, at melankolien, som en systemlogisk foregang - »historiefilosofisk « såvel som psykologisk - også kan producere kritisk indsigt.

\section{Note til oversættelsen}

Oversættelsen følger, som det vil ses, Steinhagens linje, at citere fra Benjamins 'Gesammelte Schriften', og den kalder også jæunthen bøgerne og essayene ved deres egne, tyske navne. Dels er jo meget få oversat, og de vigtigste af dem ('Om nogle motiver hos Baudelaire' især) som sagt temmelig slet, eller inkomplet ('Centralpark'), så jeg har selv oversat derfra.

Helt konsekvent er linjen dog ikke holdt, af subjektivt skønsmæssige grunde har jeg skrevet 'Historiefilosofiske teser', fordi det er den kendte titel herhjemme, skønt Benjamins egen titel bevidst var mindre pretentiøs: 'Über den Begriff der Geschichte'. Ligeså klinger Marx' hovedværker og Goethes 'Die Wahlverwandtschaften' bedre for mig som 'Kapitalen' osv. Henvisningerne er dog overalt til de tyske udgaver. 